\title{
Selection of Risk Management Strategies in Informal Construction Sector
}

\author{
Sarah Phoya, Geraldine kikwasi, Nyamagere Gladys Sospeter and Mikapagaro Novatus \\ School of Architecture, Construction Economics and Management, Ardhi University, Dar es Salaam 35276, Tanzania
}

\begin{abstract}
The informal construction sector is unregulated and operates in a risky environment, thus the need for adoption of appropriate risk management strategies for its survival is essential. Therefore, the aim of this study was to examine methods used in choosing appropriate risk response strategy in informal construction sector in Tanzania. The study involved construction workers in informal sector in Dar es Salaam and Mwanza in Tanzania. Dar es Salaam and Mwanza are among big cities in Tanzania having more informal construction workers. Questionnaires were prepared in English, translated in Kiswahili and administered by research assistants on informal construction workers. Workers were purposively selected. Out of 1,000 questionnaires distributed 849 questionnaires were fairly filled equating to $84.9 \%$. The collected data was coded and analysed using descriptive statistics mainly frequencies cross tabulation and Chi-square tests. The study established that majority of informal construction workers choose risk response strategies by using common sense followed by previous experience. Within the location, the methods significantly differ whereby Dar es Salaam was dominated by common sense and Mwanza dominated by previous experience. Likewise, use of common sense among respondents was significantly different between gender, age group, level of education and experience. This implies that apart from formal process of choosing risk response strategies, the informal construction sector has its own surviving strategies. The issue of location, gender and experience are essential for risk management in informal construction sector.
\end{abstract}

Key words: Construction, informal sector, risk response strategies.

\section{Introduction}

The importance of effective risk management has been highly recognized not only in the construction industry but also in other industries and variety of techniques have been devised to curb the negative consequences of risks. The aim of risk management is to maximize the opportunities and minimize the negative consequences of risk threats in a project or in any activities [1].

The construction industry suffers risks on both its formal and informal settings in the categories of natural, economic, technical, health and safety, and socio-demographic risks. These were identified in a number of risk management related studies [2-5]. In the event of risk manifestation, strategies have to be devised or adopted in order to minimise or eliminate the consequences of risk regardless of its setting.

Corresponding author: Sarah Phoya, lecturer, research field: risk management in informal construction.
The available risk response strategies together with their variants are traced in a number of studies [6-14]. Collectively, these strategies can be summarised as risk avoidance, reduction/mitigation, transfer/sharing, retention/acceptance. All of these strategies were derived from formal construction setting, with little or no attention given to informal construction sector. Taking into consideration that the informal construction is growing and there is strong relationship between formal and informal construction sector [15]. It should be noted that informal construction needs special attention. Selection of appropriate risk response strategies has been traditionally guided by standards documents and guidelines such as frameworks and other formal systems or documents. It is clear however that if selection of the appropriate risk response is to encompass of both formal and informal setting then the existing standards and guidelines is inadequate, since it is mainly targeted to formal setting.

The nature of informal setting is compounded with 
lack of formal contacts, lack of proper training, low salaries, high rates of accidents, financial constraints, unorganised workers $[16,17]$. With this nature of risks, it is clear that standard documents and guidelines will not guide the appropriate methods for selection of risk responses. Therefore, this study attempts to answer the question that in the event of risk exposure, how the risk response strategy is selected and whether factors such as location, gender, age group, level of education, type of employment and experience have an influence on adoption of a certain techniques in informal construction sector

\section{Literature Review}

\subsection{Overview of the Informal Construction Sector}

Informal construction sector is believed to emerge from the concept of informal economy. The informal economy is the diversified set of economic activities, enterprises, and workers that are not regulated or protected by the state [18]. On the other hand, the informal economy consists of economic activities that occur outside of formal institutional boundaries but which remain within informal institutional boundaries for large segments of society [19]. In many cases informal economy is categorized as unregistered businesses, operating in violation of labour regulations, and the sale of counterfeit products. Similarly, in the construction industry context, the informal sector is defined in various studies [15, 20-23]. In most of these definitions, the informal construction sector is regarded as comprised of illegal and unregulated individuals and enterprises working in construction related activities. In the same line, Ref. [21] defined informal construction as workers who are employed on a casual or temporary basis without any proper form of contract, as well as those who work for themselves either alone or in small groups in construction related activities. The functioning of the construction industry depends on small enterprises which work for large enterprises and partly emerge from the informal sector. Mlinga and Wells [20] determine that the formal sector depends on the informal sector on supply of labour in exchange of source of work and income. Lizarralde and Root [24] point out that the informal sector in South Africa is the only source of delivery of affordable housing for the poor. Despite its informality, the sector contributes significantly to the national growth through GDP (gross domestic product), provision of housing to the urban residents and creation of employment. Jewell et al. [25] point out the informal sector contributes $40 \%$ of GDP in developing countries and $18 \%$ in the OECD high-income countries. URT [26] discloses that in 2014 the informal construction sector employed $6.2 \%$ of the total employment. The Government of Tanzania through the construction industry policy (URT) [22] provides for recognition and promotion of sector as an integral part of the construction industry.

\subsection{Methods of Selecting Risk Management Response Strategy}

Methods of selecting risk response strategy have been broadly studied. In a number of documents and studies [1, 6, 9, 27, 28], Chinenye et al. [14] risk analysis techniques and methods of selecting risk response strategy are similar and are categorized as qualitative and quantitative. However, there are some varying opinions on this categorization as shown in Table 1. Furthermore, some the techniques used in risk identification are also used in risk analysis.

Techniques which are used in selection of risk response strategy and categorized as qualitative as well as quantitative include: expert judgment, FMECA (failure mode and effect criticality analysis), HRA (human reliability assessment), interviews, risk probability and impact assessment, risk ranking/risk index. Similarly, techniques which are for both identification and analysis of the response include: Brainstorming, CCA (cause consequence analysis), change analysis, checklist, expert judgment, FMECA, interviews, HRA and SWOT (strengths, weaknesses, opportunities and threats). In Table 1, the work of 
Table 1 Qualitative and quantitative risk analysis techniques.

\begin{tabular}{|c|c|c|c|}
\hline $\mathrm{S} / \mathrm{N}$ & Author & Qualitative & Quantitative \\
\hline 1 & {$[29]$} & $\begin{array}{l}\text { Brainstorming, checklist, hazard review, change } \\
\text { analysis and HRA, interviews, CCA, PHA } \\
\text { (preliminary hazard analysis) }\end{array}$ & $\begin{array}{l}\text { Decision tree, expected monetary value, expert judgment, } \\
\text { FMECA, fuzzy logic, SWOT, ABC analysis, risk } \\
\text { ranking/risk index }\end{array}$ \\
\hline 2 & {$[1] \&[14]$} & $\begin{array}{l}\text { Risk probability and impact assessment, } \\
\text { probability and impact matrix, risk data quality } \\
\text { assessment, risk categorization, risk urgency } \\
\text { assessment and expert judgment }\end{array}$ & $\begin{array}{l}\text { Interviewing, probability distributions, sensitivity } \\
\text { analysis, expected monetary value analysis and expert } \\
\text { judgment }\end{array}$ \\
\hline 3 & [9] \& [14] & Checklist, interviews and brainstorming & $\begin{array}{l}\text { Sensitivity analysis, probabilistic analysis, influence } \\
\text { diagram, decision tree, Monte Carlo Simulation, } \\
\text { Breakeven Analysis, Scenario Analysis }\end{array}$ \\
\hline
\end{tabular}

Chinenye et al. [14] has similar quantitative techniques to o APM (Association for Project Management) [9] and qualitative techniques to PMI (Project Management Institute) [1]. A study by Cagliano et al. [28] identifies 31 project risk management techniques but for the purpose of this study only techniques for selection of risk response and categorized as qualitative or quantitative are included in Table 1. Other techniques for risk response classified by Cagliano et al. [28] are: FMEA (failure mode and effects analysis), HAZOP (hazard and operability), SWIFT analysis and what-if analysis. The selection of risk management response strategy must take into account the source of risk, and, size and complexity of the project. Baloi [5] analyzed probability theory, certainty factors, Dempster-Shaffer theory of evidence and fuzzy logic techniques and concludes that the nature of risks under consideration is determinant in the selection of modeling and analysis techniques. De Marco and Thaheem [30] argue that complex projects require more sophisticated risk analysis techniques and simpler and routine projects may benefit from relatively simpler analysis techniques, such as qualitative techniques.

\section{Methodology}

The research focused on the informal construction workers in the two urban centers in Tanzania namely Dar es Salaam and Mwanza. The focus was on urban areas due to the fact that the construction industry can ideally be better modeled in urban than in rural areas given that the scale and intensity of these activities is more in cities and towns than in rural areas. The two cities were selected as the study area because they are top two urbanized regions in Tanzania [31]. In these two regions the focus was informal workers which are involved in construction activities such as masonry, ceiling board fixing, carpentry, electrical installation, painting, architects, brick making, iron welding for door and window grills, plumbing, and floors finishing, material producers and suppliers. The population of the study was difficult to determine, as a result it was agreed by authors that the sample size was 1,000 informal construction workers comprising of 700 and 300 from Dar es Salaam and Mwanza respectively. Due to the fact that the informal sector is not regulated, selection of workers was done using both purposive and snow ball sampling. Questionnaires were prepared in English, translated Kiswahili to enable workers to understand and respond well to the questions. After translation, questionnaires were pre-tested to five informal construction workers in Dar es Salaam and recommended modifications were done to accommodate construction site language. The pilot study also helped to identify three methods for selecting response strategy which were not found directly in the literature these are common sense, direct observation on site and available hazard data. These methods were added on the questionnaires. Questionnaires were administered by researchers and research assistants on informal construction workers. Out of 1,000 questionnaires sent out, 900 were returned with 849 fairly filled questionnaires equivalent to $84.9 \%$. Data were coded, entered into SPSS, cleaned 
and analysed using descriptive statistics. Descriptive statistics features used for analyzing data are frequencies, cross tabulation and Chi-square tests.

\section{Results}

This part presents respondents profile, methods for selection of risk management strategies and selected background factors which influence selection of risk management strategies.

\subsection{Respondents Profile}

Table 2 presents respondents location, gender, age group, experience and level of education. Results reveal majority (77.4\%) of respondents were from Dar es Salaam. As expected, male domination accounted for $87.9 \%$ of all respondents. Age wise, more than a half $(56.3 \%)$ were older than 35 years old. Experience was grouped into less experienced (less or equal to five years' experience) and experienced (over five years' experience) and majority (69.3\%) were experienced. Majority (58.2\%) had low level of education.

\subsection{Methods for Selection of Risk Management Response Strategies}

Fig. 1 presents different methods used in selection of risk management strategies. Results indicate that the dominant method was common sense followed by previous experience and available hazard data on site.

\subsection{Influence of Background Factors on Selection of Risk Management Response Strategies}

Table 3 presents other factors and their influence in selection of risk management response strategy. These factors are location, gender, age group, level of education, type of employment and experience. In assessing these factors, the expert judgment was dropped because of its low applicability. Within the location, the methods of selection of risk used in Dar es Salaam and Mwanza were significantly different whereby Dar es Salaam was leading in common sense, available hazard data and brain storming. Within gender, results were significantly different whereby common sense and previous experience were dominated

Table 2 Respondent profile.

\begin{tabular}{|c|c|c|}
\hline Profile & Frequency & Percent \\
\hline \multicolumn{3}{|l|}{ Location } \\
\hline Dar es Salaam & 657 & 77.4 \\
\hline Mwanza & 192 & 22.6 \\
\hline Total & 849 & 100.0 \\
\hline \multicolumn{3}{|l|}{ Gender } \\
\hline Male & 746 & 87.9 \\
\hline Female & 103 & 12.1 \\
\hline Total & 849 & 100.0 \\
\hline \multicolumn{3}{|l|}{ Age group } \\
\hline Less or equal to 35 years old & 366 & 43.7 \\
\hline Over 35 years old & 472 & 56.3 \\
\hline Total & 838 & 100.0 \\
\hline \multicolumn{3}{|l|}{ Level of experience } \\
\hline Less experienced & 257 & 30.7 \\
\hline Experienced & 580 & 69.3 \\
\hline Total & 837 & 100.0 \\
\hline \multicolumn{3}{|l|}{ Level of education } \\
\hline Primary education only & 468 & 58.2 \\
\hline Primary education plus VT and above & 336 & 41.8 \\
\hline Total & 804 & 100.0 \\
\hline
\end{tabular}




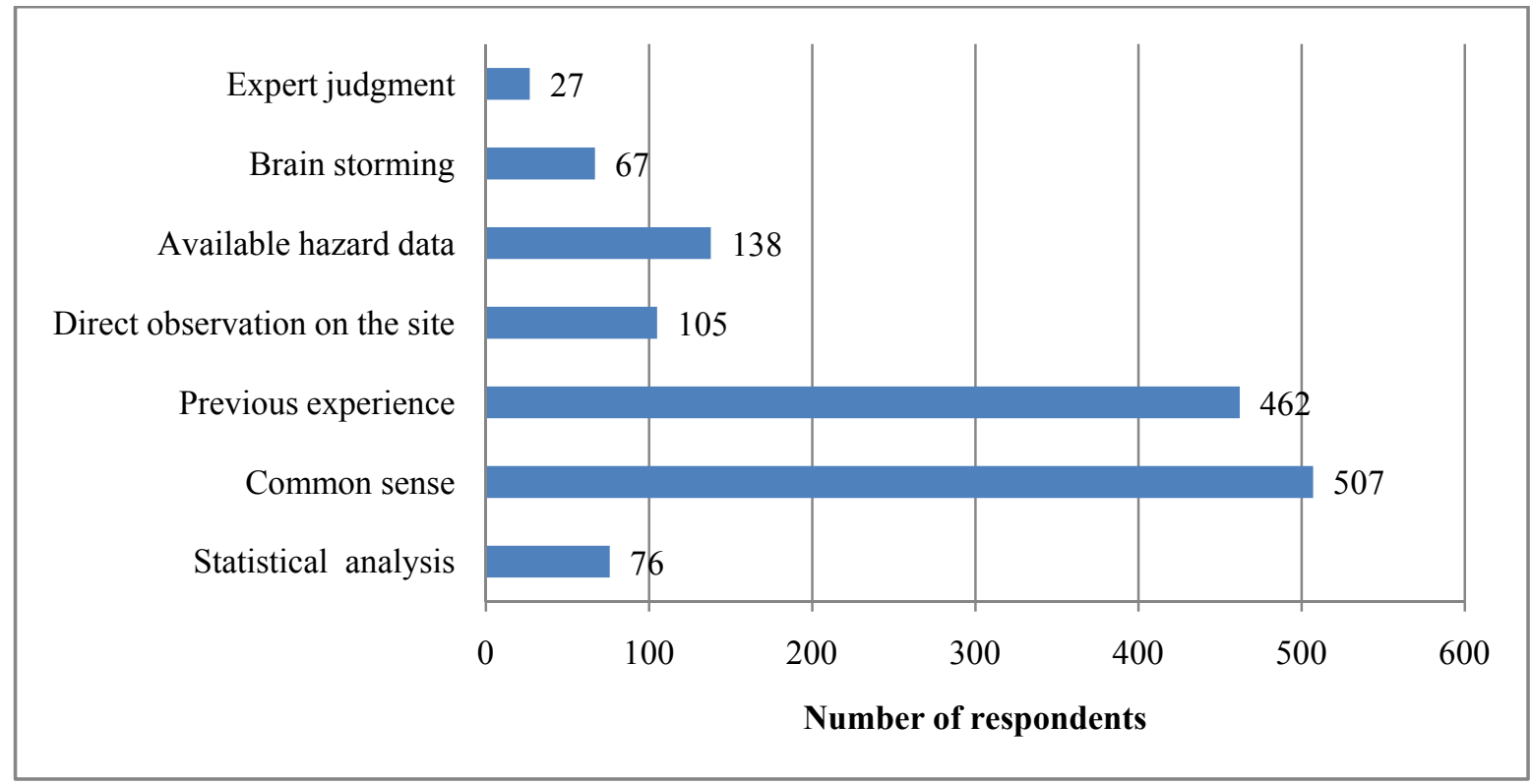

Fig. 1 Risk response selection methods.

Table 3 Background factors influence on selection of risk management response strategies.

\begin{tabular}{|c|c|c|c|c|c|c|c|c|c|}
\hline \multirow[t]{2}{*}{ Factor } & \multicolumn{3}{|c|}{ Statistical analysis } & \multicolumn{3}{|c|}{ Common sense } & \multicolumn{3}{|c|}{ Previous experience } \\
\hline & Yes & No & Sig. & Yes & No & Sig. & Yes & No & Sig. \\
\hline \multicolumn{10}{|l|}{ Location } \\
\hline DSM & $45(6.9 \%)$ & $611(93.1 \%)$ & & $425(64.8 \%)$ & $231(35.2 \%)$ & $* *$ & $346(52.7 \%)$ & $310(47.3 \%)$ & $*$ \\
\hline Mwanza & $31(16.1 \%)$ & $161(83.9 \%)$ & & $82(42.7 \%)$ & $110(57.3 \%)$ & & $116(60.4 \%)$ & $76(39.6 \%)$ & \\
\hline \multicolumn{10}{|l|}{ Gender } \\
\hline Male & $72(9.7 \%)$ & $674(90.3 \%)$ & & $455(61.0 \%)$ & $291(39.0 \%)$ & $*$ & $423(56.7 \%$ & $323(43.3 \%)$ & $* *$ \\
\hline Female & $4(3.9 \%)$ & $98(96.1 \%)$ & & $52(51 \%)$ & $50(49 \%)$ & & $39(38.2 \%)$ & $63(61.8 \%)$ & \\
\hline \multicolumn{10}{|l|}{ Age group } \\
\hline$\leq 35$ years old & $36(9.8 \%)$ & $330(90.2 \%)$ & 0.290 & $239(47.8 \%)$ & $127(34.7 \%)$ & $* *$ & $198(54.1 \%)$ & $168(45.9 \%$ & 0.499 \\
\hline$>35$ years old & $40(8.5 \%)$ & $431(91.5 \%)$ & & $261(52.2 \%)$ & $210(44.6 \%)$ & & $256(54.4)$ & $215(45.6)$ & \\
\hline \multicolumn{10}{|l|}{ Education } \\
\hline $\begin{array}{l}\text { Primary school } \\
\text { only }\end{array}$ & $22(6.6 \%)$ & $313(93.4 \%)$ & $0.028 *$ & $335(63.6 \%)$ & $122(36.4 \%)$ & $0.047^{*}$ & $180(53.7 \%)$ & $155(46.3 \%)$ & 0.421 \\
\hline $\begin{array}{l}\text { Primary school } \\
+\mathrm{VT} \text { and above }\end{array}$ & $50(10.7 \%)$ & $418(89.3 \%)$ & & $468(57.5 \%)$ & $199(42.5 \%)$ & & $256(54.7 \%)$ & $212(45.3 \%)$ & \\
\hline \multicolumn{10}{|l|}{ Employment } \\
\hline Self employed & $11(6.1 \%)$ & $170(93.9 \%)$ & 0.071 & $181(21.6 \%)$ & $81(44.8 \%)$ & 0.068 & $94(51.9 \%)$ & $87(48.1 \%)$ & 0.244 \\
\hline $\begin{array}{l}\text { Employed by } \\
\text { others }\end{array}$ & $65(9.9 \%)$ & $591(90.1 \%)$ & & $656(78.4 \%)$ & $251(38.3 \%)$ & & $362(55.2 \%)$ & $294(44.8 \%)$ & \\
\hline \multicolumn{10}{|l|}{ Experience } \\
\hline $\begin{array}{l}\text { Less experienced } \\
(\leq 5 \text { years })\end{array}$ & $16(6.2 \%)$ & $240(93.8 \%)$ & $0.042 *$ & $153(59.8 \%)$ & $103(40.2 \%)$ & 0.519 & $125(48.8 \%)$ & $131(51.2 \%)$ & $* *$ \\
\hline $\begin{array}{l}\text { Experienced ( }>5 \\
\text { years) }\end{array}$ & $59(10.2 \%)$ & $521(89.8 \%)$ & & $346(59.7 \%)$ & $234(40.3 \%)$ & & $329(56.7 \%)$ & $251(43.3 \%)$ & \\
\hline
\end{tabular}


(table 3 continued)

\begin{tabular}{|c|c|c|c|c|c|c|c|c|c|}
\hline \multirow[t]{2}{*}{ Factor } & \multicolumn{3}{|c|}{ Direct observation on site } & \multicolumn{3}{|c|}{ Available hazard data } & \multicolumn{3}{|c|}{ Brain storming } \\
\hline & Yes & No & Sig. & Yes & No & Sig. & Yes & No & Sig. \\
\hline \multicolumn{10}{|l|}{ Location } \\
\hline DSM & $68(10.4 \%)$ & $587(89.6 \%)$ & $* *$ & $124(19 \%)$ & $530(81 \%)$ & $* *$ & $57(8.7 \%)$ & $598(91.3 \%)$ & 0.073 \\
\hline Mwanza & $37(19.4 \%)$ & $154(80.6 \%)$ & & $14(7.1 \%)$ & $178(92.7 \%)$ & & $10(5.2 \%)$ & $182(94.8 \%)$ & \\
\hline Gender & & & & & & & & & 0.279 \\
\hline Male & $94(12.6 \%$ & $650(87.4 \%)$ & 0.365 & $120(16.1 \%)$ & $624(83.9 \%)$ & 0.394 & $61(8.2 \%)$ & $684(91.8 \%)$ & \\
\hline Female & $11(10.8 \%)$ & $91(89.2 \%)$ & & $18(17.6 \%)$ & $84(82.4 \%)$ & & $6(5.9 \%)$ & $96(94.1 \%)$ & \\
\hline \multicolumn{10}{|l|}{ Age group } \\
\hline$\leq 35$ years old & $47(12.9 \%)$ & $318(87.1 \%)$ & 0.341 & $51(13.9 \%)$ & $315(86.1 \%$ & 0.062 & $22(6 \%)$ & $344(94.0 \%)$ & 0.059 \\
\hline$>35$ years old & $55(11.7 \%)$ & $415(88.3$ & & $85(18.1 \%)$ & $384(81.9 \%)$ & & $43(9.1 \%)$ & $427(90.9 \%)$ & \\
\hline \multicolumn{10}{|l|}{ Education } \\
\hline $\begin{array}{l}\text { Primary school } \\
\text { only }\end{array}$ & $30(9.0 \%)$ & $303(91.0 \%)$ & $* *$ & $43(12.9 \%)$ & $290(87.1 \%)$ & $* *$ & $25(7.5 \%)$ & $309(92.5 \%)$ & \\
\hline $\begin{array}{l}\text { Primary school } \\
+ \text { VT and above }\end{array}$ & $73(15.6 \%)$ & $395(84.4 \%)$ & & $90(19.2 \%)$ & $378(80.8 \%)$ & & $37(7.9 \%)$ & $431(92.1 \%)$ & 0.468 \\
\hline \multicolumn{10}{|l|}{ Employment } \\
\hline Self employed & $22(12.2 \%)$ & $159(87.8 \%)$ & 0.481 & $33(18.2 \%)$ & $148(81.8 \%)$ & 0.244 & $11(6.1 \%)$ & $170(93.9 \%)$ & 0.194 \\
\hline $\begin{array}{l}\text { Employed by } \\
\text { others }\end{array}$ & $83(12.7 \%)$ & $571(87.3 \%)$ & & $103(15.7 \%)$ & $551(84.3 \%)$ & & $55(8.4 \%)$ & $600(91.6 \%)$ & \\
\hline \multicolumn{10}{|l|}{ Experience } \\
\hline $\begin{array}{l}\text { Less experienced } \\
\text { ( } \leq 5 \text { years) }\end{array}$ & $34(13.3 \%)$ & $225(86.7 \%)$ & 0.346 & $44(17.2 \%)$ & $212(82.8 \%)$ & 0.312 & $16(6.2 \%)$ & $240(93.8 \%)$ & 0.131 \\
\hline $\begin{array}{l}\text { Experienced ( }>5 \\
\text { years) }\end{array}$ & $70(21.1 \%)$ & $509(87.9 \%)$ & & $90(15.6 \%)$ & $488(84.4 \%)$ & & $51(8.8 \%)$ & $528(91.2 \%)$ & \\
\hline
\end{tabular}

by male. In terms of age group, results were significantly different in common sense influenced by those who are older than 35 years. On the education, results were significantly different whereby common sense, direct observation of the site and available hazard data were dominated by those who have primary education plus vocational training and above. Regarding experience, results were significantly different in previous experience dominated by those with experience of more than 5 years.

\section{Discussion}

The study reveals that majority of workers in informal construction have similar characteristic features reported by different authors in both formal and informal construction sectors. Thus the informal construction sector is characterized by male domination, youth and low level of education [17]. Low level of education implies narrow opportunity of getting formal jobs, and informal construction activities were regarded as training platform for these workers. Most of them join the construction without any skills and take a number of years learning craft skills on job through informal modes of training.

Despite of low level of education, this study reveal that majority had practical experience of more than five years in construction activities. Five years' experience is deemed adequate exposure and experienced different activities in construction [31]. However, the recognition and taping of these experiences from construction workers in informal construction has been a challenge which needs to be addressed.

The findings further reveal that the dominant methods for selecting risk response were common sense followed by previous experience and available hazard data on site. This finding supports some of previous works such as that of Refs. [32, 33]. Similarly, Dziadosza and Rejment [27] conclude that the process of selection risk response is mainly based upon experience, assumptions and human judgment. 
Common sense for the purpose of this study means sound practical judgment that is independent of specialized knowledge and training. This implies that the effort should be directed towards acquiring experience and training of the workers to ensure proper selection of risk response.

The study further revealed that there is significant difference between method of selecting risk response and background factors of gender, level of education, location and practical experience. This implied that there is no standard method for selecting risk response in informal construction sectors which is contrary to the formal construction sector. The risk response selection method depends on the location, gender, level of education, and practical experience of the workers.

\section{Conclusion}

Construction activities inherit risks and the informal construction sector is not an exception. In the event of risk manifestation, construction workers have to choose a risk response strategy by using techniques available in their settings. In this study, construction workers in the informal sector use common sense and previous experience in selection of risk response strategy. Furthermore, factors such as location, gender, age group, level of education and experience have an influence on the methods to be used in selection of the response strategy. This implies that apart from formal process that exists in the formal setting, the informal construction sector has its own surviving strategies.

In view of these findings, further study on methods for selection of risk response strategy and risk identification is necessary. Accordingly, risk management practices of the informal construction can be documented and recognized for use in the formal sector where formal risk management has partly failed.

\section{References}

[1] PMI. 2013. A Guide to Project Management Body of Knowledge (PMBoK Guide). (5th ed.). Project Management Institute Inc. Accessed March 24, 2017. http://www2.fiit.stuba.sk/ bielik/courses/msi-slov/reporty /pmbok.pdf.

[2] Finnerty, J. 1996. Project financing: Asset-based Financial Engineering. New York: John Wiley \& Sons.

[3] Mills, A. 2001. "A Systematic Approach to Risk Management for Construction." Structural Survey 19 (5): 245-52.

[4] Miller, R., and Lessard, D. 2001. "Understanding and Managing Risks in Large Engineering Projects." International Journal of Project Management 19: 437-43.

[5] Baloi, D. 2012. "Risk Analysis Techniques in Construction Engineering Projects." Journal of Risk Analysis and Crisis Response 2 (2): 115-23.

[6] Naji, H. I., and Ali, H. R. 2017. "Risk Response Selection in Construction Projects." Journal of Civil Engineering 3 (12): 1208-21.

[7] Schieg, M. 2006. "Risk Management in Construction Project Management." Journal of Business Economics and Management 7 (2): 77-83.

[8] Yusuwan, N. M., Adnan, H., and Omar, A. F. 2008. "Clients' Perspectives of Risk Management Practice in Malaysian Construction Industry." Journal of Politics and Law 1 (3): 121-30.

[9] The Association for Project Management. 2008. "Project Risk Analysis and Management." Accessed March 6, 2017. http://www.apm.org.uk.

[10] Berg, H. 2010. "Risk Management: Procedures, Methods and Experiences." RT\&A 2 (17): 79-95.

[11] Naphade, P. V., and Bhangale, P. P. 2013. "Study on the Risk Management, Risk Treatment Strategies and Insurance in Construction Industries." Accessed March 24, 2016. http://www.ijitee.org/attachments/File/v3i4/D120 2093413.pdf.

[12] Habib, A., and Rashid, S. 2013. "The Relational Analysis and Effect of Risk Management Techniques on Project Outcomes in Development Sector: A Case of NGOs \& INGOs." Journal of Business Economics and Political Science 2 (4): 91-105.

[13] Abdul-Rahman, H., Wang, C., and Mohamad, F. S. 2015. "Implementation of Risk Management in Malaysian Construction Industry: Case Studies." Journal of Construction Engineering. Article ID 192742: 1-6.

[14] Chinenye, E. U., Okorocha, A. B., Aku, K., and Okogbuo, A. F. 2015. "Project Risk Management Issues in the Nigerian Construction Industry." International Journal of Engineering and Technical Research (IJETR) 3 (1): 217-32.

[15] Aikael, J., and Mkenda, B. K. 2014. "Determinants of Informal Employment: A Case of Tanzania's Construction Industry." BOJE: Botswana Journal of Economics 12 (2): 51-73.

[16] Wells, J. 2007. "Informality in the Construction Industry." Construction Management and Economics 25: 87-93. 
[17] Jason, A., and Wells, J. 2010. "Employment Relationships and Organizing Strategies in the Informal Construction Sector." African Studies Quarterly 11 (2 \& 3): 107-24.

[18] ILO. 2013. "Informal Economy." Accessed February 24, 2016. http://www.ilo.org/global/topics/employmentpromo tion/informal-economy/lang--en/index.htm.

[19] Webb, J. W., Ireland, R. D., and Ketchen, D. J. 2014. "Towards a Greater Understanding of Entrepreneurship and Strategy in the Informal Economy." Strategic Entrepreneurship Journal 8 (1): 1-15.

[20] Mlinga, R., and Wells, J. 2002. "Collaboration between Formal and Informal Enterprises in the Construction Sector in Tanzania." Habitat International 26: 269-80.

[21] ILO. 2002. "Decent Work and the Informal Economy." Report of the Director-General, International Labour Conference, 90th Session, Geneva.

[22] URT. 2003. Construction Industry Policy. Dar es Salaam, Tanzania: Ministry of Works.

[23] Jason, A. 2008. "Organizing Informal Workers in the Urban Economy: The Case of the Construction Industry in Dar es Salaam, Tanzania." Habitat International 32: 192-202.

[24] Lizarralde, G., and Root, D. 2008. "The Informal Construction Sector and the Inefficiency of Low Cost Housing Markets." Construction Management and Economics 26 (2): 103-13.

[25] Jewell, C., Flagman, R., and Catell, K. 2012. "The Effects of the Informal Sector on Construction." http://dx.doi.org/10.1061/40754(183)78.

[26] United Republic of Tanzania. URT. 2015 Economic Survey 2014. Ministry of Finance, Dar es Salaam.

[27] Dziadosza, A., and Rejment, M. 2015. "Risk Analysis in Construction Projects: Chosen Methods." Procedia Engineering 122: 258-65.

[28] Cagliano, A. C., Grimaldi, S., and Rafele, C. 2015. "Choosing Project Risk Management Techniques. Atheoretical Framework." Journal of Risk Research 18 (2): 232-48.

[29] De Marco, A., and Thaheem, M. J. 2014. "Risk Analysis in Construction Projects: A Practical Selection Methodology." American Journal of Applied Sciences 11 (1): 74-84.

[30] NBS. 2014. "Unemployment Estimates for the Year 2013." Accessed April 3, 2016. http://www.nbs.go.tz.

[31] Musonda, I. 2012. "Construction Health and Safety (H\&S) Performance Improvement. A Client-Centred Model." Ph.D. thesis, University of Johannesburg.

[32] Mahendra, P. A., Pitroda, J. R., and Bhavsar, J. J. 2013. “A Study of Risk Management Techniques for Construction Projects in Developing Countries." International Journal of Innovative Technology and Exploring Engineering 3 (5): $139-42$.

[33] Akintoye, A. S., and MacLeod, M. 1997. "Risk Analysis and Management in Construction." International Journal of Project Management 15 (1): 31-8. 